\title{
Going Concern: Where Is It Going?
}

\author{
Clemense Ehoff Jr., Central Washington University, USA
}

Dahli Gray, Keiser University, USA

\begin{abstract}
On June 26, 2013, the Financial Accounting Standards Board (FASB) issued an exposure draft concerning disclosure of uncertainties surrounding the going concern presumption. This exposure draft is the FASB's most recent attempt to bring closure to a project that began in 2007. This paper examines the going concern presumption and the FASB's treatment of the going concern from 2007 to the present.
\end{abstract}

Keywords: Going Concern Presumption; Substantial Doubt; GAAP; GAAS

\section{INTRODUCTION}

\begin{abstract}
nvestors like good news about their investments and they also want to know about financial distress early. Statement on Auditing Standards (SAS) 59 - "The Auditor's Consideration of an Entity's Ability to Continue as a Going Concern (1988)" - was supposed to be the early warning signal for potential financial distress to investors, bankers, and other users. Instead, it became the source of debate and disagreement for twenty-five years and it continues to be an unresolved issue for the Financial Accounting Standards Board (FASB). On June 26, 2013, the FASB issued a second exposure draft concerning disclosure of uncertainties surrounding the going concern presumption. This is the most recent attempt to bring closure to a project it began in 2007 . This paper examines the going concern presumption and the FASB's treatment of the going concern from 2007 to the present.
\end{abstract}

\section{BACKGROUND}

In 1988, the American Institute of Certified Public Accountants (AICPA) (1988) issued SAS 59 - "The Auditor's Consideration of an Entity's Ability to Continue as a Going Concern." This 11-page document directed auditors to evaluate whether substantial doubt exists about the entity's ability to continue as a going concern. If there is substantial doubt, auditors must evaluate management's plans to mitigate the situation. If the auditor still has substantial doubt about the entity's ability to continue as a going concern (even though the auditor is not responsible for predicting future conditions), a modifying paragraph would be added to the unqualified report informing the reader of the situation.

Unfortunately, financial distress triggers intense scrutiny. During 2001 and 2002, twelve of twenty companies sent $\$ 381$ billion of assets into bankruptcy and all twelve got unqualified opinions on their most recent audit reports (Venuti, 2004). The business community wanted answers. SAS 59 was supposed to be the "safety valve," giving investors an early warning of possible financial danger. Why did it fail?

\section{SCRUTINY OF SAS 59}

There is no conclusive answer as to why the going concern issue was not raised in the audit reports of the aforementioned companies that ultimately went bankrupt. Upon closer examination of SAS 59, several factors may have contributed to the eventual outcome.

First, there is language used in SAS 59 that is vague, allowing for broad interpretation. "Substantial doubt" (AICPA, p. 1), "for a reasonable period of time" and "appropriate evidential matter" (SAS 59, p. 2), and "the likelihood that such plans can be effectively implemented" (AICPA, p. 3) give the auditor lots of room for interpreting the standard. The use of language subject to broad interpretation might prove useful in matters of 
position defense, but it also opens the door for completely different determinations, all in compliance with the standard. It is therefore possible that a going concern paragraph might have appeared on the audit report on one or more of the aforementioned bankruptcies had the audit been performed by different auditors.

Second, SAS 59 places the responsibility for evaluating whether there is substantial doubt about the entity's ability to continue as a going concern for a reasonable period of time squarely on the auditor's shoulders (AICPA, $p$. 2). Further, the auditor is required to assess the effectiveness of management's plans for mitigating the going concern issue (AICPA, p. 3). Yet, the Standard states that the auditor is not responsible for predicting future conditions or events (AICPA, p. 3). Then management must be responsible for predicting future conditions or events, but management is not responsible for the going concern issue. This somewhat confusing description of responsibilities gives the auditor and the entity an "escape" from going concern culpability.

Finally, Venuti (2004), Vanstraelan (2003), and others suggest that the going concern disclosure is a selffulfilling prophecy. It seems quite possible for any businessperson to intuitively arrive at the same conclusion. The mere suggestion of bad financial distress sends investors and bankers quickly running away. The auditor is left with either 1) a client with a recovery plan destined for failure, or 2) a client that is looking for another auditor who is willing to avert the going concern disclosure, commonly known as opinion shopping. In either case, the auditor is faced with potentially losing revenue from a somewhat subjective disclosure. It appears that auditors hesitate disclosing a going concern issue.

SAS 59 was supposed to be a "safety valve" for investors. Instead, it was often perceived as a "death sentence" for organizations; so it was time for revision of SAS 59.

\section{EXPOSURE DRAFT}

In May 2007, the FASB added Going Concern and the related Liquidation Basis of Accounting to the list of projects (Minutes, June 13, 2007) and on October 9, 2008 (FASB Exposure Draft, 2008), the Going Concern Exposure Draft was issued. This draft was essentially the same document as SAS 59, with two exceptions. First, the Exposure Draft shifted responsibility for evaluating a reporting entity's ability to continue as a going concern from the auditor to management. Second, the time frame was changed from 12 months to at least, but not limited to, 12 months (a decision to simplify future convergence with International Financial Reporting Standards).

The FASB received 29 comment letters (FASB, Comment Letter Summary). The significant issues were 1) type of information required and time horizon, 2) disclosures required, 3) definition of going concern, 4) effective date of final statement, and 5) auditing literature. Indeed, clear guidance dominated the responses (FASB Comment Letter Summary). In 2010, and after much deliberation, the FASB decided to delay its work on the going concern issue and shift its focus to uncertainties and the liquidation basis of accounting (Minutes, 4/2/2010).

\section{RECENT EXAMPLES}

This section summarizes recent examples of going concern questions. Johnson (2013) reported that the "Dodd-Frank financial reform legislation of 2010 ends forever the ability of the United States government to provide support to failing financial companies." The comment was made relative to large financial institutions such as AIG. Sorkin (2012) quoted a financial analyst who said, "Trends at J.C. Penney are obviously getting worse, not better, and we are becoming more and more convinced that sales in 2013 will also decline, which could lead to a going concern problem next year." Kozinn (2013) reported that the independent auditors of the Nashville Symphony Orchestra "questioned whether the orchestra could "continue as a going concern." Sharp reported a "serious negative operating cash flow which raised 'serious doubts' about its ability to continue as a going concern and said it was taking steps, including pay cuts, voluntary redundancies and asset sales, to generate cash flow" (Tabuchi, 2012). The examples illustrate the significance of the going concern issue that supports the need for revision resulting in the 2013 exposure draft. 


\section{EXPOSURE DRAFT}

In 2013, the FASB returned to work on the going concern project and issued a new exposure draft "Disclosure of Uncertainties about an Entity's Going Concern Presumption" (FASB Exposure Draft, 2013). After some introductory comments and a list of questions for respondents, the exposure draft begins by defining the going concern presumption as "... an entity will continue to operate such that it will be able to realize its assets and meet its obligations in the ordinary course of business"(FASB Exposure Draft, 2013, p. 9). The draft states that substantial doubt about an entity's ability to continue as a going concern exists when it is probable that an entity will not be able to meet its obligations, as they become due within 24 months after the financial statement date, after giving consideration to the mitigating effect of all of management's plans (Exposure Draft, 2013, p. 10). The exposure draft describes disclosure requirements in considerable detail, including when to include plan outside the ordinary course of business - a set of requirements for Securities and Exchange Commission (SEC) filers and a set for nonSEC filers (FASB Exposure Draft, 2013, pp. 11-16).

This exposure draft cures many of the issues raised above concerning SAS 59 as well as the 2008 exposure draft. First, the going concern issue will be part of Generally Accepted Accounting Principles. In doing so, responsibility for the financial statements, the substantial doubt determination, plans for mitigation of going concern issues, and operating decision authority rest with management. Second, many of the definition issues raised earlier have been addressed. It appears that the use of language that allows broad interpretation has been minimized. All things considered, this exposure draft is a welcome improvement for the treatment of going concern issues.

\section{CONCLUSION}

It has been twenty-five years since SAS 59 was issued and it has been six years since the FASB placed the going concern issue on the project list. The 2013 exposure draft appears to cure many of the issues that were raised above. The shifting of responsibility from the auditor to management is a major step forward and many believe that it will solve the problems mentioned above. Unfortunately, the self-fulfilling prophecy issue has not been resolved and disclosure of financial distress or possible financial distress will continue to frighten investors and bankers. So, where is going concern going? The FASB is moving the going concern in a forward direction, but there is still a long way to go.

\section{AUTHOR INFORMATION}

Clemense Ehoff Jr., CPA, CGMA, is an Assistant Accounting Professor, Central Washington University, Ellensburg, Washington. He holds a Ph. D in Business Administration from San Francisco's Golden Gate University. He has more than 30 years professional business experience and has held full-time faculty and adjunct positions at universities predominantly in the Eastern United States. Over the last ten years, Dr. Ehoff has been involved in teaching accounting and tax courses in an online platform. He operates a consulting and tax practice. He has published articles in Elevator World, and other journals. E-mail: drehoff@comcast.net (Corresponding author)

Dahli Gray, CPA, CMA, CFE, is an Accounting Professor at Keiser University. She earned her doctoral degree from the George Washington University. She has over 40 journal articles, including articles in journals such as the Journal of Accounting Research and the Journal of Accountancy. She has made over 60 professional presentations including at American Accounting Association meetings plus at conferences in the United States and other countries such as Japan. She has been full-time faculty at schools such as the University of Notre Dame and American University. She currently is a full-time faculty member with Keiser University. She is a CPA, CMA, and Certified Fraud Examiner. E-mail: dahli.gray@ waldenu.edu

\section{REFERENCES}

1. American Institute of Certified Public Accountants (AICPA). (1988). Statement on auditing standards (SAS) 59. The auditor's consideration of an entity's ability to continue as a going concern. AICPA. 1-11. 
2. Financial Accounting Standards Board (FASB). (2008, December 22). Going concern comment letter summary. FASB. Retrieved from http://www.fasb.org/cs/ContentServer?c=Document_C\&pagename =FASB \%2FDocument_C\%2FDocumentPage\&cid=1176154539333

3. FASB. (2008, October 9). Exposure draft. Proposed statement of financial accounting standards: Going concern. FASB. Retrieved from http://www.fasb.org/ed_going_concern.pdf

4. FASB. (2013, June 26). Exposure draft. Proposed accounting standards update. Presentation of financial statements (Topic 205). Disclosure of uncertainties about an entity's going concern presumption. FASB. Retrieved from: http://www.fasb.org/cs/BlobServer?blobkey=id\&blobnocache=true \&blobwhere $=1175827205763 \&$ blobheader=application \%2Fpdf\&blobcol=urldata\&blobtable=MungoBlobs

5. FASB. (2007, June 13). Minutes of the May 30, 2007 board meeting: Going concern and liquidation basis of accounting. FASB. Retrieved from http://www.fasb.org/board_meeting_minutes/05-3007_going_concern.pdf

6. FASB. (2010, April 2). Minutes of the March 31, 2010 Board Meeting: Going Concern. FASB. Retrieved from http://www.fasb.org/cs/ContentServer?c=Document_C\&pagename=FASB\%2FDocument_C $\% 2$ FDocumentPage\&cid=1176157108145

7. Johnson, S. (2013. August 1). Sadly, too big to fail is not over. New York Times. Retrieved from http://economix.blogs.nytimes.com/2013/08/01/sadly-too-big-to-fail-is-not-over/

8. Kozinn, A. (2013, June 7). Foreclosure is new blow to Nashville symphony. New York Times. Retrieved from http://www.nytimes.com/2013/06/08/arts/music/nashville-symphony-hall-faces-foreclosure.html

9. Sorkin, A. R. (2012, November 12). A dose of realism for the chief of JP Penney. New York Times. Retrieved from http://dealbook.nytimes.com/2012/11/12/a-dose-of-realism-for-the-chief-of-j-c-penney/

10. Tabuchi, H. (2012, November 1). Sony Sharp and Panasonic report significant losses. New York Times. Retrieved from http://www.nytimes.com/2012/11/02/business/global/sony-sharp-and-panasonic-reportsignificant-losses.html

11. Vanstraelen, A. (2003). Going-concern opinions, auditor switching, and the self-fulfilling prophecy effect examined in the regulatory context of Belgium. Journal of Accounting, Auditing and Finance, 18, 231-253.

12. Venuti, E. K. (2004, May). The going-concern assumption revisited: Assigning a company’s future viability. The CPA journal. Retrieved from http://www.nysscpa.org/cpajournal/2004/504/

essentials/p40.htm 